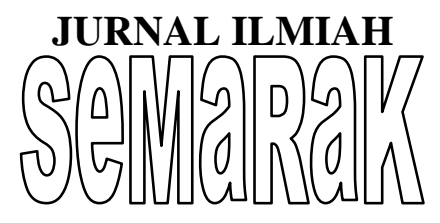

P-ISSN 2615-6849

Jurnal Semarak,Vol. 1,No.1,Februari 2018 , Hal (66-82)

@ Prodi Manajemen Fakultas Ekonomi Universitas Pamulang

\title{
PENGARUH MOTIVASI DAN DISIPLIN TERHADAP PRODUKTIVITAS KERJA KARYAWAN PADA PT. NADI SUWARNA BUMI
}

\author{
Denok Sunarsi \\ Dosen Fakultas Ekonomi Universitas Pamulang \\ Email : denoksunarsi@gmail.com
}

\begin{abstract}
Abstrak
Tujuan penelitian ini untuk mengetahui seberapa besar pengaruh motivasi dan disiplin terhadap produktivitas kerja karyawan pada PT. Nadi Suwarna Bumi.

Jenis penelitian merupakan penelitian kuantitatif dianalisis menggunakan statistik penulis menjadikan karyawan PT. Nadi Suwarna Bumi sebagai populasi totalnya berjumlah 150 karyawan. Adapun jumlah sampel diperoleh dari perhitungan Slovin dengan tingkat galat sebesar 10\% diperoleh hasil 60 responden. Analisis data menggunakan SPSS Versi 22. Teknik uji sampling menggunakan metode sensus Hasil penelitian ini menunjukan bahwa variabel Motivasi dan Disiplin berpengaruh positif dan simultan terhadap Produktivitas kerja karyawan pada PT. Nadi Suwarna Bumi. Hal ini dibuktikan dengan hasil nilai $\mathrm{F}$ hitung $=$ $8098,471>3,160$ atau $\left(F_{\text {hitung }}>F_{\text {tabel }}\right)$ sehingga $\mathrm{H}_{0}$ ditolak dan $\mathrm{H}_{1}$ diterima. Artinya terdapat pengaruh positif dan signifikan secara simultan antara motivasi dan Disiplin $\left(\mathrm{X}_{2}\right)$ secara simultan terhadap Produktivitas kerja (Y) karyawan pada PT. Nadi Suwarna Bumi
\end{abstract}

\section{Kata Kunci : Motivasi, Disiplin, Produktivitas}

\begin{abstract}
The purpose of this study to determine how much influence motivation and discipline on employee productivity at PT. Nadi Suwarna Bumi.

The type of research is quantitative research is analyzed using statistics the author makes the employees of PT. The Suwarna Bumi pulse as a total population of 150 employees. The number of samples obtained from Slovin calculation with error rate of $10 \%$ obtained by 60 respondents. Data analysis using SPSS Version 22. Sampling technique using census method

The results of this study showed that the variables Motivation and Discipline have a positive and simultaneous effect on employee productivity at PT. Nadi Suwarna Bumi. This is evidenced by the result of the value of $F$ arithmetic $=8098,471>3,160$ or (Fcount $>$ Ftabel) so that $\mathrm{HO}$ is rejected and $\mathrm{Hl}$ accepted. This means there is a positive and significant influence simultaneously between motivation and Discipline (X2) simultaneously to Work productivity (Y) employees at PT. Nadi Suwarna Bumi.
\end{abstract}

Keywords:Motivation,Discipline,Productivity 


\section{A. Pendahuluan}

Agar perusahaan bisa bersaing, maka tuntutan akan kesadaran akan pentingnya kualitas Sumber Daya Manusia (SDM) yang merupakan salah satu respon dalam menyikapi perubahan tersebut sangatlah penting. Sumber Daya Manusia (SDM) yang berkualitas sangat penting artinya bagi suatu perusahaan.Bahkan ketersediaan SDM yang berkualitas diyakini sebagai kunci yang utama keberhasilan suatu perusahaan atau organisasi.Oleh karena itu, untuk mewujudkan SDM yang berkualitas, perlunya peran serta yang optimal dari pihak perusahaan sendiri sebagai wadah pengembangan SDM itu sendiri (investasi SDM).

Untuk mencapai tujuan perusahaan diperlukan suatu sikap kedisiplinan kerja karyawan agar produktivitas kerja dari masing-masing karyawan tersebut dapat ditingkatkan, yang mana pada gilirannya produktivitas kerja karyawan secara keseluruhan akan meningkat pula, kedisiplinan kerja karyawan tersebut akan memelihara sikap mental dan watak mereka untuk semakin menyadari atau memahami terhadap tugas dan tanggungjawab di dalam pekerjaannya. Adapun segala usaha perusahaan di dalam melakukan tindakan kedisiplinan kerja karyawan pada akhirnya akan bermuara pada tercapainya produktivitas kerja karyawan. Demikian pula yang terjadi pada PT. Nadi Suwarna Bumi, dimana masih terlihat kurangnya disiplin karyawan, sehingga akan turut menurunkan tingkat produktivitas kerja karyawan. Banyak diantaranya yang terlambat hadir dari jam yang telah ditentukan, karyawan yang sering melakukan izin akan mencerminkan tinggi rendahnya tingkat kedisiplinan kerja karyawan. Setiap perusahaan akan menemui persoalan - persoalan mengenai Penindakan yang konsisten dalam melaksanakan peraturan, setiap karyawan dituntut untuk mematuhi peraturan yang berlaku di perusahaan tersebut sesuai dengan perjanjian kerja yang telah disepakati bersama.

Disiplin karyawan yang sebaikbaiknya itu harus ditanamkan dalam diri setiap karyawan, sebaliknya bukan atas paksaan atau karena adanya punishment (peringatan) maupun rewards (penghargaan) akan tetapi berdasarkan kesadaran dari dalam diri karyawan masing-masing. Untuk mendapatkan disiplin yang baik, karyawan harus taat terhadap aturan kehadiran/kedisiplinan, taat terhadap peraturan perusahaan, taat terhadap peraturan perilaku (kode etik) dalam bekerja dan taat terhadap aturan lainnya diperusahaan.Berikut disajikan hasil pengukuran disiplin pada PT. Nadi Suwarna Bumi

Produktivitas kerja akan terwujud jika para karyawan mempunyai kemampuan dalam menyelesaikan pekerjaan atau tugas yang sudah menjadi tanggungjawabnya masing-masing. Oleh karena itu pimpinan harus dapat memberikan suatu motivasi dan kedisiplinan pada karyawannya, agar dapat meningkatkan produktivitas kerja karyawan pada perusahaan dan para karyawan pun sadar akan kewajibannya untuk melaksanakan tugas dengan sebaik baiknya.

Dari gambaran singkat di atas, maka penulis tertarik mengangkat fenomena tersebut kedalam sebuah penelitian dengan judul "Pengaruh Motivasi dan Disiplin Terhadap Produktivitas Kerja Karyawan Pada PT. Nadi Suwarna Bumi."

\section{B. Perumusan Masalah}

Berdasarkan latar belakang yang telah diungkapkan di atas, maka rumusan masalah dalam penelitian ini adalah :

1. Bagaimana pengaruh motivasi terhadap produktivitas kerja ?

2. Bagaimana pengaruh disiplin terhadap produktivitas kerja? 
3. Seberapa besar pengaruh motivasi dan disiplin terhadap produktivitas kerja secara simultan?

\section{Kerangka Berpikir}

Kerangka berfikir penelitian ini dapat digambarkan sebagai berikut :

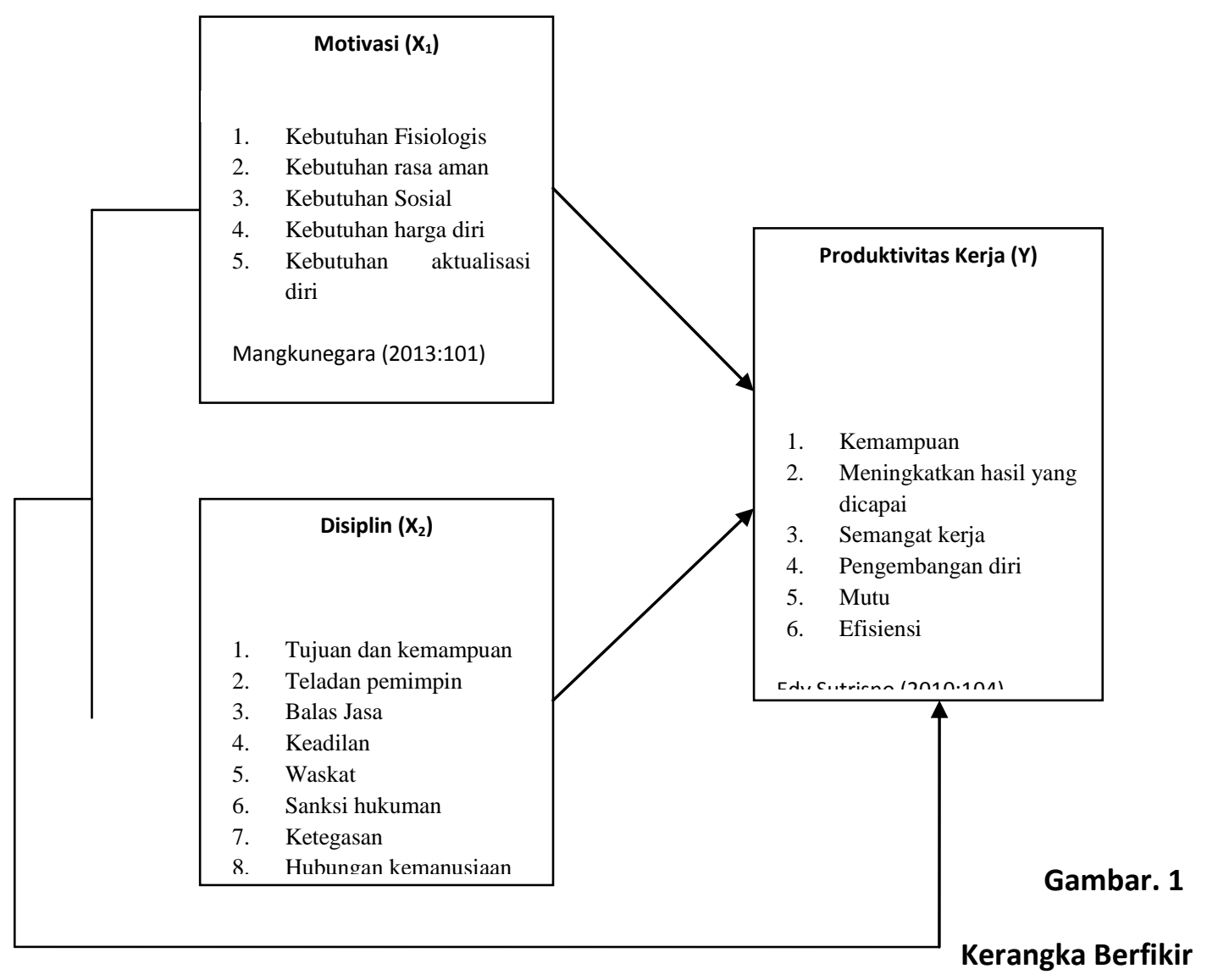

\section{Landasan Teori}

\section{Motivasi}

Menurut Hasibuan (2013:143) mengatakan bahwa "motivasi adalah Pemberian daya penggerak yang menciptakan kegairahan kerja seseorang, agar mereka mau bekerja sama, bekerja efektif dan tergintegrasi dengan segala daya upaya untuk mencapai kepuasan".

Robbins dalam Edy Sutrisno (2016:117) menyatakan motivasi ialah "suatu kerelaan berusaha seoptimal mungkin dalam pencapaian tujuan organisasi yang dipengaruhi oleh kemampuan usaha memuaskan beberapa kebutuhan individu".

Wibowo (2014:323) menambahkan motivasi sebagai dorongan terhadap serangkaian proses perilaku manusia pada pencapaian tujuan. Manusia memiliki dorongan untuk dapat mencapai tujuan yang diinginkan.

Berdasarkan uraian tersebut di atas, diperoleh kesimpulan bahwa motivasi merupakan unsur penggerak yang mendasari seseorang dalam melaksanakan pekerjaan.

\section{Disiplin}

Disiplin menurut Veithzal Rivai (2011:825) adalah suatu alat yang dipergunakan para manajer untuk berkomunikasi dengan karyawan agar mereka bersedia untuk mengubah suatu 


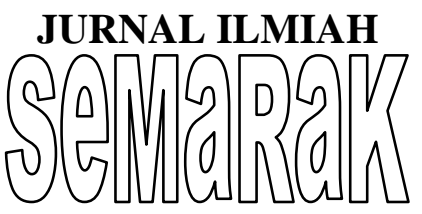

perilaku serta sebagai suatu upaya untuk meningkatkan kesadaran dan kesediaan seseorang dalam memenuhi segala peraturan perusahaan.

Singodimenjo dalam Edy Sutrisno (2016:86) mendefinisikan disiplin sebagai sikap keadaan dan kerelaan seseorang untuk mematuhi dan mentaati normanorma peraturan yang berlaku di sekitarnya.

Keith Davis dalam Mangkunegara (2013:129) disiplin adalah sebagai pelaksanaan manajemen untuk memperteguh pedoman-pedoman organisasi.

Mangkunegara

menambahkan disiplin merupakan ukuran aktivitas organisasi untuk memanfaatkan semua sumbangan atau kemampuan yang ada secara optimal untuk mencapai tujuan, dengan mentaati segala peraturan yang telah ditetapkan.

Sedangkan Hasibuan (2013:193) menyatakan bahwa disiplin adalah kesadaran dan kesediaan seseorang mentaati semua peraturan-peraturan dan norma-norma sosial yang berlaku. Disiplin yang baik mencerminkan besarnya tanggung jawab seseorang terhadap tugastugas yang diberikan kepadanya. Hal ini akan mendorong gairah kerja, semangat kerja, dan terwujudnya tujuan organisasi.

Dari beberapa pengertian disiplin yang dikemukakan oleh beberapa ahli dapat disimpulkan bahwa disiplin adalah sikap kesadaran, kerelaan, dan kesediaan seseorang dalam mematuhi dan mentaati peraturan-peraturan dan norma-norma sosial yang berlaku di lingkungan sekitar.

\section{Produktivitas Kerja}

Tujuan dari setiap kegiatan yag dilakukan oleh setiap organisasi kepada karyawan adalah untuk meningkatkan produktivitas kerja karyawannya. Karena dengan produktivitas kerja yang tinggi mereka dapat memberikan hasil yang sesuai dengan tujuan yang diharapkan oleh organisasi. Untuk lebih jelas mengenai pengertian produktivitas kerja maka penulis mengutip dari beberapa pendapat para ahli antara lain:

Menurut Sondang P. Siagian (2011:187) produktivitas pada dasarnya mencakup sikap mental yang selalu mempunyai pandangan bahwa kehidupan hari ini harus lebih baik dari hari kemarin dan hari esok harus lebih baik dari hari ini cara kerja kemarin dan hasil yang dicapai besok juga harus lebih baik atau banyak diperoleh hari ini.

Menurut Eddy Sutrisno (2016:109) produktivitas kerja adalah keefektifan dari penggunaan tenaga kerja dan peralatan yang intinya mengarah pada tujuan yang sama, bahwa produktivitas kerja adalah rasio dari hasil kinerja dengan waktu yang dibutuhkan untuk menghasilkan produk dari seorang tenaga kerja.

Melayu S.P Hasibuan (2013:94) menambahkan bahwa produktivitas kerja adalah perbandingan antara output dengan input, dimana outputnya harus mempunyai nilai tambahan dan teknik pengejarannya yang lebih baik.

Secara filosofi produktivitas mengandung pandangan hidup dan sikap mental yang selalu berusaha untuk meningkatkan mutu kehidupan. Keadaan hari ini harus lebih baik dari yang sebelunnya.

Dari beberapa pengertian di atas penulis menyimpulkan bahwa produktivitas kerja adalah perbandingan antara hasil kinerja actual (output) dengan pengorbanan (input) yang dikeluarkan seseorang/organisasi untuk mencapainya. Produktivitas dikaitkan dengan keefektifan dari penggunaan tenaga kerja dan peralatan yang intinya mengarah pada tujuan yang sama, bahwa produktivitas kerja adalah rasio dari hasil kinerja dengan waktu yang dibutuhkan untuk menghasilkan produk dari seorang tenaga kerja 


\section{E. Metodologi Penelitian}

Jenis penelitian merupakan penelitian kuantitatif karena data penelitian berupa angka-angka yang nantinya akan dianalisis menggunakan statistik Penelitian ini

\section{Populasi Dan Sampel}

Pada penelitian ini, penulis karyawan PT. Nadi Suwarna Bumi sebagai populasi totalnya berjumlah 150 karyawan. Adapun jumlah sampel diperoleh dari perhitungan yang dikemukakan oleh Slovin dalam Husain (2003 : 146) dengan tingakat galat sebesar $10 \%$ diperoleh hasil 60 responden. Pengumpulan data yang dipergunakan dalam penelitian ini antara lain observasi, penyebaran kuisioner dan dokumentasi. Dalam penelitian ini peneliti juga menggunakan kuesioner atau angket yang disebar pada responden (sampel penelitian) untuk mengetahui data tentang motivasi dan disiplin terhadap produktivitas kerja karyawan. Dalam penilaian angket, digunakan skala likert dengan 5 alternatif jawaban yaitu sangat setuju, setuju, ragu-ragu, tidak setuju, sangat tidak setuju.

\section{Analisis Data}

Analisis data Analisis data yang digunakan dalam penelitian ini adalah uji validitas dan uji reliabilitas. Pengujian validitas menggunakan rumus korelasi pearson product moment, dengan ketentuan jika hiung $\mathrm{r}>$ tabel $\mathrm{r}$, berarti instrumen valid. Pengujian reliabilitas dalam penelitian ini menggunakan nilai Alpha Coanbach dengan ketentuan jika Alpha Croanbach ( hitung $r$ ) $>0,60$ berarti instrumen tersebut reliabel. Teknik analsis data antara lain uji asumsi klasik dan analisis regresi ganda. Uji asumsi klasik terdiri dari uji normalitas, uji multikolinearitas, uji heteroskedastisitas, uji autokorelasi.

\section{Uji Normalitas}

Data yang telah terkumpul harus diuji normalitasnya terlebih dahulu guna bertujuan untuk mengetahui pengaruh motivasi dan disiplin terhadap produktivitas kerja karyawan pada PT. Nadi Suwarna Bumi.

mengetahui apakah data penelitian berasal dari populasi yang sebarannya normal atau tidak. Pengujian normalitas menggunakan One-sample Kolmogorov-Smirnov Test dengan SPSS 22.0 for windows. Dengan ketentuan, jika nilai Asymp Sig > 0,05 maka data berdistribusi normal.

\section{Uji Multikolinearitas}

Uji Multikolinearitas dilakukan untuk mengetahui ada tidaknya kemiripan yang dimiliki oleh satu variabel independent dengan variabel independen yang lain dalam satu model. Pengujian multikolinearitas dalam penelitian ini menngunakan VIF (Variance Inflation Factor), dengan ketentuan jika nilai tolerance $>0,1$ dan nilai $\mathrm{VIF}<10$, maka data tidak maka data tidak mengalami multikolinearitas.

\section{Uji Heterokedastisitas}

Pengujian dilakukan untuk mengetahui apakah terjadi penyimpangan model karena gangguan variabel yang berbeda antar observasi ke observasi lain. Untuk mengetahui apakah terjadi heteroskedastisitas atau tidak, dapat dilihat pada gambar Scattreplot, jika pada gambar scatterplot tidak ada pola yang jelas serta titiktitik menyebar diatas dan dibawah angka 0 pada sumbu $\mathrm{Y}$, maka tidak terjadi heterokedastisistas.

\section{Analisis Regresi Ganda}

Teknik analisis regresi ganda dipergunakan untuk mengetahui pengaruh motivasi dan disiplin terhadap produktivitas kerja karyawan PT. Nadi Suwarna Bumi. Dengan persamaan regresi $Y=a+b_{1} X_{1}+X_{2} b_{2}$

Teknik pengujian hipotesis menggunakan uji parsial dan uji simultan 


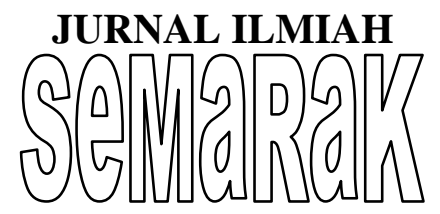

\section{P-ISSN 2615-6849}

Jurnal Semarak,Vol. 1,No.1,Februari 2018 , Hal (66-82)

@Prodi Manajemen Fakultas Ekonomi Universitas Pamulang

dengan teknik probabilitas, dengan cara membandingkan nilai probabilitas Sig dengan taraf signifikansi 0,05 . Jika nilai probabilitas sig $<0,05$ maka signifikan.

\section{Koefisien Determinasi}

Pengujian koefisien determinasi bertujuan untuk mengetahui besarnya pengaruh antar variabel. Nilai koefisien determinasi menunjukkan presentase variasi nilai variabel dependen yang dapat dijelaskan oleh persamaan regresi yang dihasilkan.

\section{F. Analisis Hasil Penelitian dan Pembahasan}

\section{Penilaian Responden Terhadap Variabel-Variabel}

Variabel yang digunakan dalam penelitian ini adalah Motivasi $\left(\mathrm{X}_{1}\right)$ dan Disiplin $\left(\mathrm{X}_{2}\right)$ serta Produktivitas Kerja (Y), penilaian dilakukan dengan menyebar kuesioner kepada karyawan pada PT. Nadi Suwarna Bumi. Jumlah sampel yang diambil adalah 60 responden/ karyawan

Metode yang diambil dalam penelitian ini adalah metode pengukuran Likert. Dimana pernyataan mengandung lima alternatif jawaban. Dan bentuk pernyataan telah disusun menggunakan pengukuran Likert yang diberi bobot sebagai berikut:

Tabel 1

Skala Likert Interpretasi

\begin{tabular}{|cc|c|}
\hline Jawaban & Bobot Skor \\
\hline Sangat Setuju & (SS) & 5 \\
\hline Setuju & (S) & 4 \\
\hline Ragu - ragu & (R) & 3 \\
\hline Tidak Setuju & (TS) & 2 \\
\hline Sangat Tidak Setuju & (STS) & 1 \\
\hline
\end{tabular}

Sumber : Sugiyono, 2014:86

a. Motivasi $\left(\mathbf{X}_{1}\right)$

Dari hasil variabel Motivasi $\left(\mathrm{X}_{1}\right)$ yang diperoleh melalui kuosioner terhadap 60 orang karyawan pada PT. Nadi Suwarna Bumi. digambarkan dalam sebuah grafik muncul sebagai berikut:

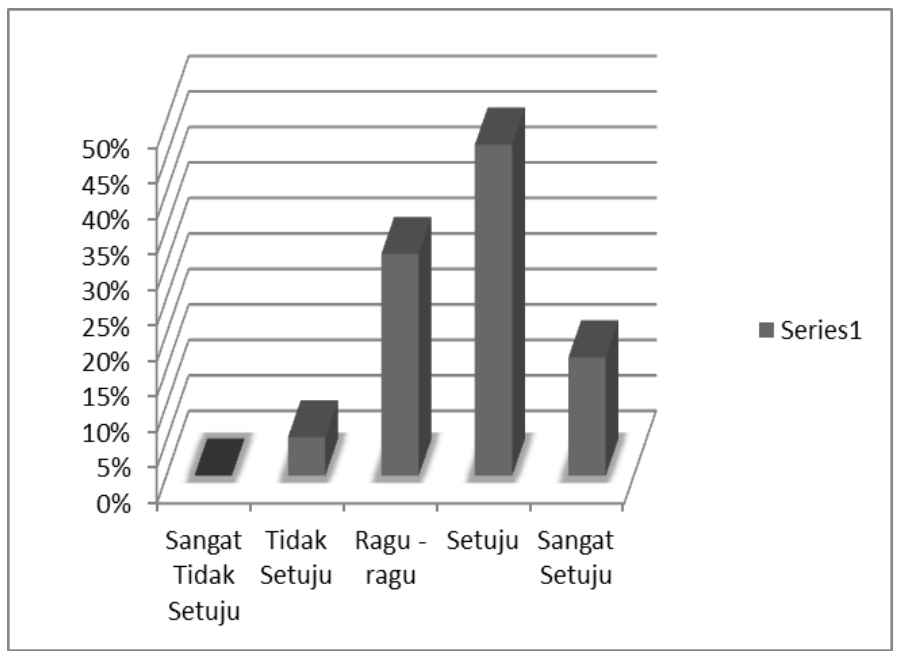

Hal ini menunjukkan bahwa pendapat responden mengenai motivasi sudah baik. 


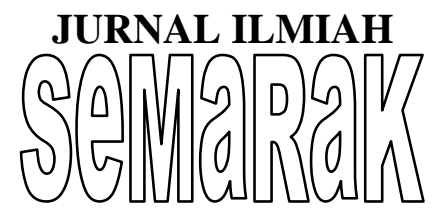

P-ISSN 2615-6849

Jurnal Semarak,Vol. 1,No.1,Februari 2018 , Hal (66-82)

@Prodi Manajemen Fakultas Ekonomi Universitas Pamulang

\section{b. Disiplin $\left(\mathbf{X}_{2}\right)$}

Dari hasil variabel Disiplin $\left(\mathrm{X}_{2}\right)$ yang diperoleh melalui kuosioner terhadap 60 orang karyawan pada PT. Nadi Suwarna Bumi digambarkan dalam bentuk grafik akan muncul seperti berikut :

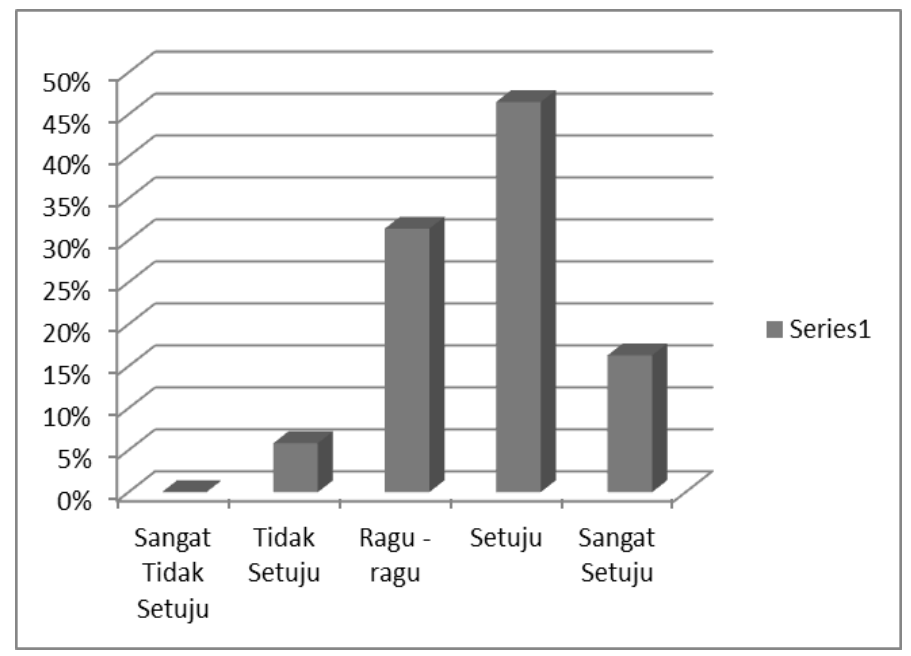

Hal ini menunjukkan bahwa pendapat responden mengenai Disiplin sudah baik.

Untuk lebih baik lagi perlu peningkatan disiplin yaitu dengan menghimbau kepada karyawan untuk tetap mentaati peraturan yang telah ditetapkan oleh perusahaan.
Produktivitas kerja menggambarkan hasil dari suatu pekerjaan. Produktivitas juga dijeaskan mencakup sikap mental yang selalu mempunyai pandangan bahwa kehidupan hari ini harus lebih baik dari hari kemarin dan hari esok harus lebih baik dari hari ini cara kerja kemarin dan hasil yang dicapai besok juga harus lebih baik atau banyak diperoleh hari ini. Dapat digambarkan dalam sebuah grafik maka muncul sebagai berikut :

\section{muncul sebagai berikut:}

\section{c. Produktivitas kerja (Y)}

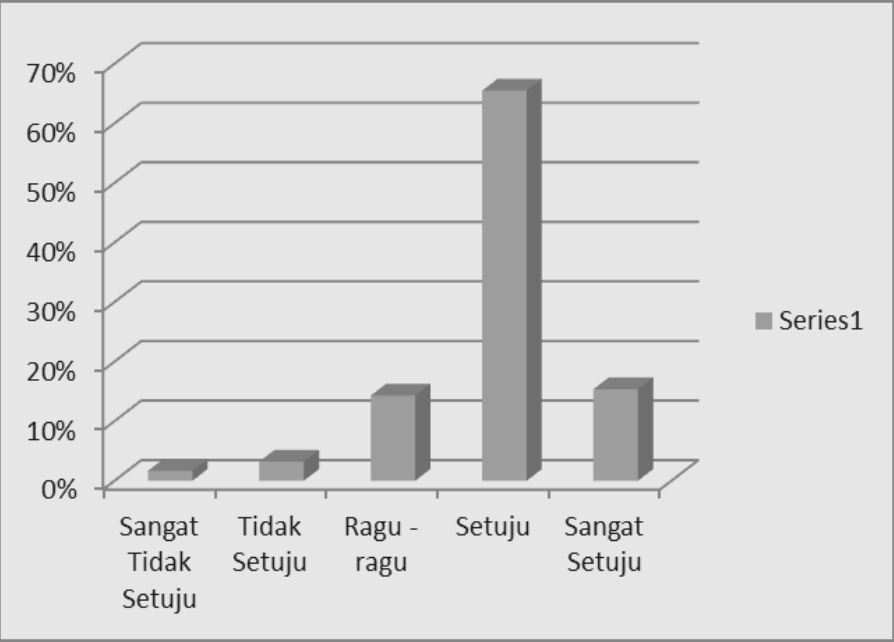

Hal ini menunjukkan bahwa pendapat responden mengenai produktivitas kerja sudah baik.

Untuk lebih baik lagi perlu pemberian waktu penyelesaian pekerjaan yang jelas serta mengukur kemampuan kerja karyawan dalam menyelesaikan pekerjaan nya serta memberikan evaluasi bagi pekerjaan yang sebelumnya.

\section{Hasil Pengolahan Data}

a. Uji Validitas (Uji Instrumen) 
Sebelum dilakukan pengolahan data terlebih dahulu dilakukan uji validitas instrumen (butir pertanyaan) yang digunakan agar dapat diketahui kelayakan dari pengguna butir pernyataan dalam penelitian yang dilakukan. Uji validitas ini digunakan untuk menguji pernyataan pada kuesioner valid atau tidak, dalam arti dapat dipergunakan atau tidak.

Selanjutnya untuk mengolah uji validitas, peneliti menggunakan program SPSS versi 22 dengan kriteria sebagai berikut:

a. Jika nilai $\mathrm{r}_{\text {hitung }}$ lebih besar dari $r_{\text {tabel }}$ $\left(\mathrm{r}_{\text {hitung }}>r_{\text {tabel }}\right)$ dan nilai $\mathrm{r}$ positif, maka butir pernyataan dikatakan valid. b. Jika nilai $\mathrm{r}_{\text {hitung }}$ lebih kecil dari $r_{\text {tabel }}$ $\left(\mathrm{r}_{\text {hitung }}>r_{\text {tabel }}\right)$ dan nilai $\mathrm{r}$ negatif, maka butir pernyataan dikatakan tidak valid.

Adapun nilai $\mathrm{r}_{\text {tabel }}$ untuk 60 responden dengan taraf signifikansi $\alpha=0,05$ (5\%) dengan tingkat kepercayaan pengujiannya adalah $95 \%$.

Berikut ini hasil perhitungan uji validitas variabel motivasi $\left(\mathrm{X}_{1}\right)$ yang diolah dengan program SPSS sebagai berikut :.

Pengujian Validitas variabel Motivasi $\left(\mathrm{X}_{1}\right)$

\section{Tabel 2}

Uji Validitas Variabel Motivasi $\left(\mathbf{X}_{1}\right)$

\begin{tabular}{|c|c|c|c|c|}
\hline No & Penyataan & r hitung & r tabel & Ket. Butir \\
\hline 1 & Butir Pernyataan 1 & 0,465 & 0,254 & Valid \\
\hline 2 & Butir Pernyataan 2 & 0,650 & 0,254 & Valid \\
\hline 3 & Butir Pernyataan 3 & 0,352 & 0,254 & Valid \\
\hline 4 & Butir Pernyataan 4 & 0,300 & 0,254 & Valid \\
\hline 5 & Butir Pernyataan 5 & 0,423 & 0,254 & Valid \\
\hline 6 & Butir Pernyataan 6 & 0,395 & 0,254 & Valid \\
\hline 7 & Butir Pernyataan 7 & 0,527 & 0,254 & Valid \\
\hline 8 & Butir Pernyataan 8 & 0,587 & 0,254 & Valid \\
\hline 9 & Butir Pernyataan 9 & 0,432 & 0,254 & Valid \\
\hline 10 & Butir Pernyataan 10 & 0,595 & 0,254 & Valid \\
\hline 11 & Butir Pernyataan 11 & 0,446 & 0,254 & Valid \\
\hline 12 & Butir Pernyataan 12 & 0,623 & 0,254 & Valid \\
\hline
\end{tabular}

Sumber : Data Primer, tahun 2017, (diolah)

Dari data tabel di atas, dapat dilihat bahwa dari 12 butir pernyataan variabel Motivasi $\left(\mathrm{X}_{1}\right)$ semua butir pernyataan dinayatakan valid, dimana semua itemitem pernyataan memiliki nilai corrected item total correlation lebih besar dari 0,254 .

Pengujian Validitas variabel Disiplin $\left(\mathrm{X}_{2}\right)$

Tabel 3 Uji Validitas Variabel Disiplin $\left(\mathbf{X}_{2}\right)$

\begin{tabular}{|c|c|c|c|c|}
\hline No & Penyataan & r hitung & r tabel & Ket. Butir \\
\hline 1 & Butir Pernyataan 1 & 0,449 & 0,254 & Valid \\
\hline 2 & Butir Pernyataan 2 & 0,616 & 0,254 & Valid \\
\hline
\end{tabular}




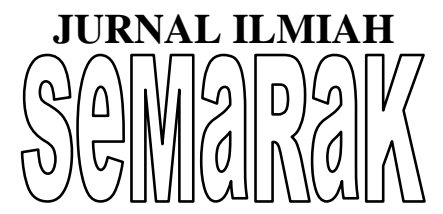

P-ISSN 2615-6849

Jurnal Semarak,Vol. 1,No.1,Februari 2018 , Hal (66-82)

@Prodi Manajemen Fakultas Ekonomi Universitas Pamulang

\begin{tabular}{|r|c|c|c|c|}
\hline 3 & Butir Pernyataan 3 & 0,410 & 0,254 & Valid \\
\hline 4 & Butir Pernyataan 4 & 0,346 & 0,254 & Valid \\
\hline 5 & Butir Pernyataan 5 & 0,415 & 0,254 & Valid \\
\hline 6 & Butir Pernyataan 6 & 0,464 & 0,254 & Valid \\
\hline 7 & Butir Pernyataan 7 & 0,510 & 0,254 & Valid \\
\hline 8 & Butir Pernyataan 8 & 0,560 & 0,254 & Valid \\
\hline 9 & Butir Pernyataan 9 & 0,404 & 0,254 & Valid \\
\hline 10 & Butir Pernyataan 10 & 0,545 & 0,254 & Valid \\
\hline 11 & Butir Pernyataan 11 & 0,419 & 0,254 & Valid \\
\hline 12 & Butir Pernyataan 12 & 0,587 & 0,254 & Valid \\
\hline 13 & Butir Pernyataan 13 & 0,449 & 0,254 & Valid \\
\hline 14 & Butir Pernyataan 14 & 0,616 & 0,254 & Valid \\
\hline 15 & Butir Pernyataan 15 & 0,410 & 0,254 & Valid \\
\hline 16 & Butir Pernyataan 16 & 0,346 & 0,254 & Valid \\
\hline 17 & Butir Pernyataan 17 & 0,415 & 0,254 & Valid \\
\hline 18 & Butir Pernyataan 18 & 0,464 & 0,254 & Valid \\
\hline
\end{tabular}

Sumber : Data Primer, tahun 2017, (diolah)

Dari data tabel di atas, dapat dilihat bahwa dari 18 butir pernyataan variabel disiplin $\left(\mathrm{X}_{2}\right)$ semua butir pernyataan dinayatakan valid, dimana semua item-item

pernyataan memiliki nilai corrected item total correlation lebih besar dari 0,254.

Pengujian Validitas variabel Produktivitas Karyawan (Y)

Tabel 4 Uji Validitas Variabel Produktivitas Karyawan (Y)

\begin{tabular}{|c|c|c|c|c|}
\hline No & Penyataan & r hitung & r tabel & Ket. Butir \\
\hline 1 & Butir Pernyataan 1 & 0,584 & 0,254 & Valid \\
\hline 2 & Butir Pernyataan 2 & 0,535 & 0,254 & Valid \\
\hline 3 & Butir Pernyataan 3 & 0,364 & 0,254 & Valid \\
\hline 4 & Butir Pernyataan 4 & 0,611 & 0,254 & Valid \\
\hline 5 & Butir Pernyataan 5 & 0,611 & 0,254 & Valid \\
\hline 6 & Butir Pernyataan 6 & 0,611 & 0,254 & Valid \\
\hline 7 & Butir Pernyataan 7 & 0,304 & 0,254 & Valid \\
\hline 8 & Butir Pernyataan 8 & 0,357 & 0,254 & Valid \\
\hline 9 & Butir Pernyataan 9 & 0,524 & 0,254 & Valid \\
\hline 10 & Butir Pernyataan 10 & 0,503 & 0,254 & Valid \\
\hline 11 & Butir Pernyataan 11 & 0,477 & 0,254 & Valid \\
\hline 12 & Butir Pernyataan 12 & 0,568 & 0,254 & Valid \\
\hline 13 & Butir Pernyataan 13 & 0,763 & 0,254 & Valid \\
\hline 14 & Butir Pernyataan 14 & 0,265 & 0,254 & Valid \\
\hline
\end{tabular}

Sumber : Data Primer, tahun 2017, (diolah)

Dari data tabel di atas, dapat dilihat bahwa dari 14 butir pernyataan variabel produktivitas

kerja (Y) semua butir pernyataan dinayatakan valid, dimana semua item-item pernyataan memiliki 


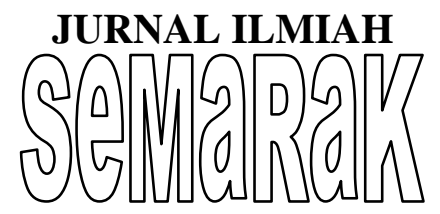

P-ISSN 2615-6849

Jurnal Semarak,Vol. 1,No.1,Februari 2018 , Hal (66-82)

@Prodi Manajemen Fakultas Ekonomi Universitas Pamulang

nilai corrected item total correlation lebih besar dari 0,254.

\section{b. Uji Reliabilitas}

Suatu kuesioner dikatakan reliabel atau handal jika jawaban responden terhadap pernyataan adalah konsisten atau stabil dari waktu ke waktu (Sugiyono, 2008:183). Uji reliabilitas adalah tingkat kestabilan suatu alat pengukur dalam mengukur suatu gejala. Kriteria untuk mengolah uji reliabilitas adalah sebagai berikut :

a) Jika nilai Cronbach Alpha $>\mathrm{r}_{\text {tabel }}$ dan nilai $r$ positif, maka butir pernyataan dikatakan reliabel. b) Jika nilai Cronbach Alpha $<\mathrm{r}_{\text {tabel }}$ dan nilai $r$ negatif, maka butir pernyataan dikatakan tidak reliabel.

c) Jika nilai Cronbach Alpha < Sandard Cronbach Alpha 0,60, maka butir pernyataan dikatakan tidak reliabel.

d) Jika nilai Cronbach Alpha > Sandard Cronbach Alpha 0,60, maka butir pernyataan dikatakan reliabel.

Adapun nilai $\mathrm{r}_{\text {tabel }}$ untuk 60 responden dengan taraf signifikansi $\alpha=0,05(5 \%)$ artinya tingkat kepercayaan pengujiannya adalah 95\%. Hasil uji reliabilitas dalam penelitian ini dilakukan dengan menggunakan program SPSS Versi 22, hasilnya sebagai berikut :

Tabel 5 Hasil Uji Reliabilitas Data

\begin{tabular}{|c|c|c|c|c|}
\hline No & Variabel & r hitung & r tabel & Kesimpulan \\
\hline 1 & Motivasi $\left(\mathrm{X}_{1}\right)$ & 0,696 & 0,254 & Reliabel \\
\hline 2 & Disiplin $\left(\mathrm{X}_{2}\right)$ & 0,788 & 0,254 & Reliabel \\
\hline 3 & Produktivitas Kerja $(\mathrm{Y})$ & 0,720 & 0,254 & Reliabel \\
\hline
\end{tabular}

Sumber : Data Primer, tahun 2017 diolah dengan SPSS versi 22.

Berdasarkan hasil uji reliabilitas pada tabel di atas, dapat diketahui bahwa seluruh variabel yang digunakan dinyatakan reliablel, karena $r$ hitung lebih besar dari $r$ tabel.

\section{c. Uji Asumsi Klasik (Uji Prasyarat) \\ 1) Uji Normalitas}

Uji normalitas bertujuan untuk menguji apakah dalam model regresi, variabel dependen dan variabel independen berdistribusi normal atau berdistribusi tidak normal. Deteksi pengambilan keputusan adalah dengan syarat penyebaran titik titik residual mengikuti arah garis diagonal. Adapun hasil uji normalitas diolah dengan

SPSS versi 22, dibawah ini :

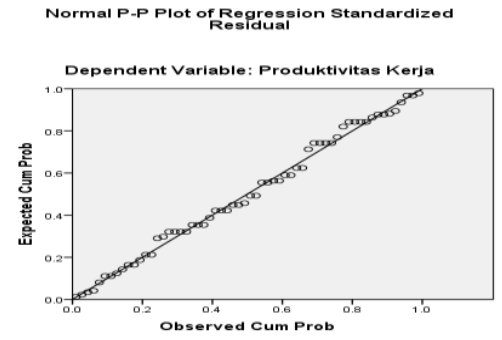

Sumber : Data Primer, tahun 2017 diolah dengan SPSS versi 22 


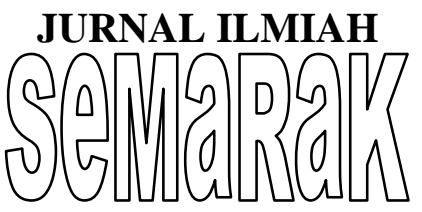

\section{P-ISSN 2615-6849}

Jurnal Semarak,Vol. 1,No.1,Februari 2018 , Hal (66-82)

@Prodi Manajemen Fakultas Ekonomi Universitas Pamulang

Pada gambar grafik diatas dapat dilihat bahwa grafik normal probability plot menunjukkan pola grafik yang normal. Hal ini terlihat dari titik-titik yang menyebar disekitar grafik normal. Hal ini terlihat dari titik-titik yang menyebar disekitar garis diagonal dan penyebarannya mengikuti garis diagonal.

Dengan penyebaran yang mengikuti alur garis diagonal tersebut maka dapat disimpulkan bahwa model regresi layak diapaki karena memenuhi asumsi normalitas.

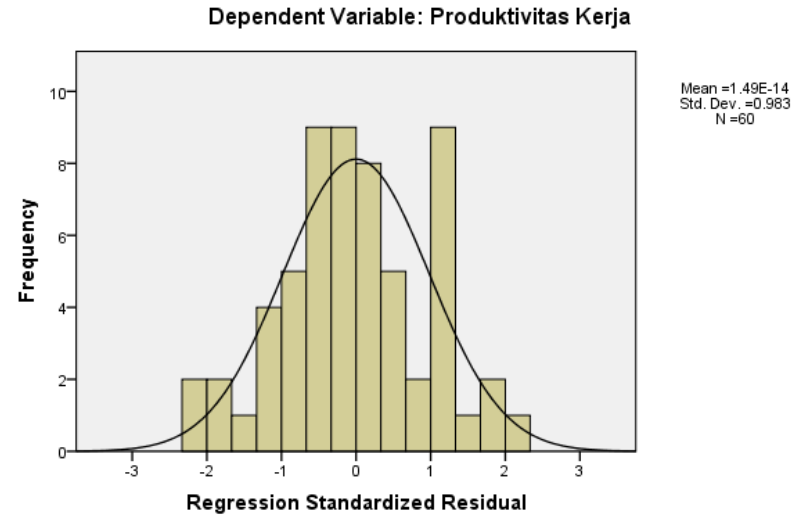

Sumber : Data Primer, tahun 2017, diolah dengan SPSS versi 22

Gambar 3 Histogram Uji Normalitas Data

Pada gambar diatas dapat dilihat bahwa grafik histogram yang memberikan pola distribusi yang normal (tidak terjadi kemencengan). Kedua grafik diatas menunjukkan bahwa model regresi layak dipakai karena memiliki asumsi normalitas.

\section{2) Uji Heteroskedastisitas}

Uji heteroskedastisitas dilakukan dengan tujuan untuk menguji apakah dalam sebuah model regresi terjadi ketidaksamaan varians residual dari satu pengamatan ke pengamatan yang lain tetap. Salah satu cara atau tehnik untuk mendeteksi telah terjadi heteroskedastisitas atau tidak adalah dengan melihat grafik scatter plot dimana antara nilai prediksi variabel terikat (ZPRED) dan nilai residualnya (SRESID).

Jika titik-titik pada gambar yang dihasilkan membentuk pola tertentu yang teratur seperti gelombang besar melebar, kemudian menyempit maka telah terjadi heteroskedastisitas. Namun jika titik-titik menyebar diatas dan dibawah angka 0 pada sumbu $\mathrm{Y}$ tanpa membentuk pola tertentu, maka model tersebut tidak terjadi heteroskedastisitas.

Adapun hasil uji heteroskedastisitas dalam penelitian ini diolah dengan menggunakan program SPSS versi 22 yang hasilnya dapat dilihat pada gambar berikut ini: 


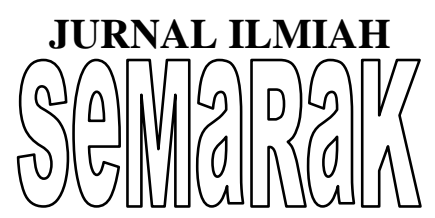

P-ISSN 2615-6849

Jurnal Semarak,Vol. 1,No.1,Februari 2018 , Hal (66-82)

@Prodi Manajemen Fakultas Ekonomi Universitas Pamulang

Scatterplot

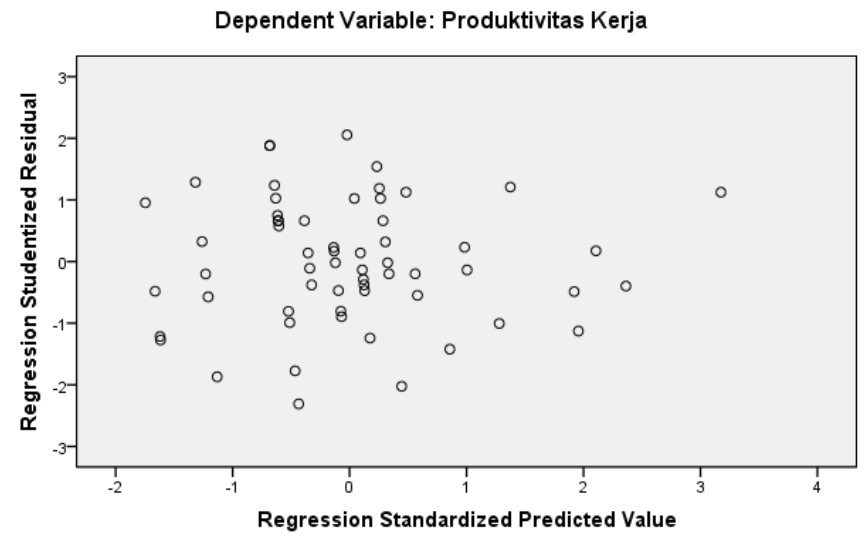

Sumber : Data Primer, tahun 2017, diolah dengan SPSS Versi 22

Gambar 4 Hasil Uji Heteroskedastisitas

Pada gambar tersebut, dapat dilihat bahwa titik-titik pada grafik scatterplot tidak mempunyai pola penyebaran yang jelas dan titik-titik tersebut menyebar di atas dan dibawah angka 0 pada sumbu Y, dengan demikian hal ini menunjukkan bahwa tidak terdapat gangguan heteroskedastisitas.

\section{3) Uji Multikolinearitas}

Uji multikolinearitas bertujuan untuk menguji apakah model regresi ditemukan adanya korelasi antar variabel independen. Model regresi yang baik seharusnya tidak terjadi korelasi di antara variabel independen. Untuk mendeteksi ada

\section{Tabel 6}

Hasil Uji Multikolinearitas Dengan Produktivitas Kerja Sebagai Variabel Dependen Coefficients $^{\mathrm{a}}$

\begin{tabular}{|c|c|c|c|c|c|c|c|}
\hline \multirow{2}{*}{ Model } & \multicolumn{2}{|c|}{$\begin{array}{c}\text { Unstandardized } \\
\text { Coefficients }\end{array}$} & $\begin{array}{c}\text { Standardized } \\
\text { Coefficients }\end{array}$ & \multirow{2}{*}{ T } & \multirow{2}{*}{ Sig. } & \multicolumn{2}{|c|}{$\begin{array}{c}\text { Collinearity } \\
\text { Statistics }\end{array}$} \\
\cline { 2 - 4 } & $\mathbf{B}$ & $\begin{array}{c}\text { Std. } \\
\text { Error }\end{array}$ & Beta & & & Tolerance & VIF \\
\hline (Constant) & 52.381 & .352 & & 148.715 & .000 & & \\
Motivasi & .048 & .008 & .049 & 6.188 & .000 & 1.000 & 1.000 \\
Disiplin & 1.000 & .008 & .997 & 127.117 & .000 & 1.000 & 1.000 \\
\hline
\end{tabular}

a. Dependent Variabel: Produktivitas Kerja

Sumber : Data Primer, tahun 2017, diolah dengan SPSS Versi 22 tidaknya multikoliniearitas dalam model regresi dapat dilihat dari tolerance value atau Variance Inflation Factor (VIF) dengan ketentuan sebagai berikut:

a. Jika nilai VIF diatas nilai 10 atau tolerance value dibawah 0,10 maka terjadi multikolinearitas

b. Jika nilai VIF dibawah nilai 10 atau tolerance value diatas 0,10 , maka tidak terjadi multikolinearitas

Hasil uji multikolinieritas dilakukan dengan menggunakan SPSS Versi 22 dengan hasil sebagai berikut : 


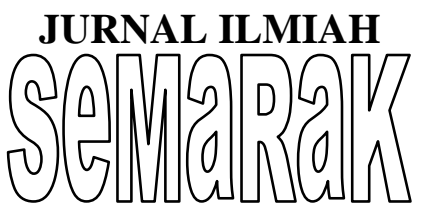

\section{P-ISSN 2615-6849}

Jurnal Semarak,Vol. 1,No.1,Februari 2018 , Hal (66-82)

@ Prodi Manajemen Fakultas Ekonomi Universitas Pamulang

Pada tabel diatas, memperlihatkan bahwa nilai Variance Inflation Factor (VIF) untuk variabel Motivasi $\left(\mathrm{X}_{1}\right)$ diperoleh sebesar 1,000 dan Disiplin $\left(\mathrm{X}_{2}\right)$ diperoleh sebesar 1,000 dimana masing-masing nilai tolerance variabel bebas kurang dari 1 dan nilai VIF kurang dari 10, dengan demikian model regresi ini tidak terjadi korelasi antar variabel independen didalam persamaan itu sendiri atau tidak ada multikolinearitas.

\section{4) Uji Autokorelasi}

Uji autokorelasi digunakan untuk mengetahui ada atau tidaknya penyimpangan korelasi antar anggota sampel. Untuk mengetahui adanya autokorelasi, dilakukan pengujian DurbinWatson (DW). Untuk mengetahui ada tidaknya autokorelasi Uji Darbin-Watson (DW test) berikut ini kriteria yang menjadi acuannya:

Tabel 7

Pedoman Interpretasi Uji Durbin-Watson

\begin{tabular}{|c|c|}
\hline Kriteria & Keterangan \\
\hline$<1$ & Ada autokorelasi \\
\hline $1,1-1,54$ & Tanpa kesimpulan \\
\hline $1,55-2,46$ & Tidak ada autokorelasi \\
\hline $2,46-2,9$ & Tanpa kesimpulan \\
\hline$>2,9$ & Ada autokorelasi \\
\hline
\end{tabular}

Sumber : Sugiyono (2014:184)

Berikut ini hasil uji Autokorelasi dengan uji Durbin-Watson yang diolah dengan SPSS versi 22, sebagai berikut :

Tabel 8 Uji Durbin-Watson Model Summary ${ }^{b}$

\begin{tabular}{|c|c|c|c|c|c|}
\hline Model & $\mathrm{R}$ & R Square & $\begin{array}{c}\text { Adjusted R } \\
\text { Square }\end{array}$ & $\begin{array}{c}\text { Std. Error of the } \\
\text { Estimate }\end{array}$ & Durbin-Watson \\
\hline 1 & $.998^{\mathrm{a}}$ & .996 & .996 & .270 & 2.356 \\
\hline
\end{tabular}

Sumber : Data Primer, tahun 2016 yang telah diolah dengan SPSS Versi 22

Dari tabel diatas, diperoleh nilai Durbin-Watson sebesar 2.356 dan berada diantara $(1,550$ - 2,460) sesuai dengan ketentuan maka model regresi ini tidak ada autokorelasi.

\section{d. Analisis Regresi Linier Berganda}

Uji regresi berganda ini dimaksudkan untuk mengetahui seberapa besar pengaruh variabel $\mathrm{X}_{1}$ dan $\mathrm{X}_{2}$ terhadap variabel $\mathrm{Y}$.
Dalam penelitian ini adalah motivasi (X1) dan disiplin (X2) produktivitas kerja (Y).

Berikut ini hasil olahan data regresi dengan SPSS versi 22 yang dapat dilihat pada tabel berikut ini :

\section{Tabel 9 \\ Hasil Pengolahan Regresi Berganda Variabel Motivasi $\left(\mathbf{X}_{1}\right)$ dan Disiplin $\left(\mathbf{X}_{2}\right)$ Coefficients $^{\mathbf{a}}$}




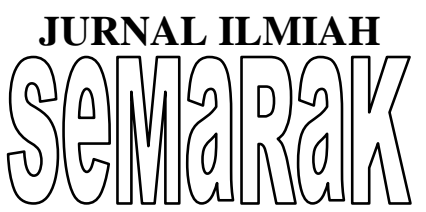

P-ISSN 2615-6849

Jurnal Semarak,Vol. 1,No.1,Februari 2018 , Hal (66-82)

@Prodi Manajemen Fakultas Ekonomi Universitas Pamulang

\begin{tabular}{|c|c|c|c|c|c|c|}
\hline \multirow{2}{*}{ Model } & \multicolumn{2}{|c|}{$\begin{array}{c}\text { Unstandardized } \\
\text { Coefficients }\end{array}$} & $\begin{array}{c}\text { Standardized } \\
\text { Coefficients }\end{array}$ & \multirow{2}{*}{$\mathrm{t}$} & \multirow{2}{*}{ Sig. } \\
\cline { 2 - 5 } & $\mathrm{B}$ & $\begin{array}{c}\text { Std. } \\
\text { Error }\end{array}$ & Beta & & \\
\cline { 2 - 5 } & (Constant) & 52.381 & .352 & & 148.715 & .000 \\
1 & Motivasi (X1) & .048 & .008 & .049 & 6.188 & .000 \\
& Disiplin (X2) & 1.000 & .008 & .997 & 127.117 & .000 \\
\hline
\end{tabular}

a. Dependent Variabel: Produktivitas Kerja (Y)

Sumber : Data Primer tahun 2017, diolah dengan SPSS Versi 22.

Berdasarkan hasil perhitungan regresi pada tabel diatas, diperoleh persamaan regresinya $\mathrm{Y}=52,381+0,048 \mathrm{X}_{1}+1,000$ $\mathrm{X}_{2}$. Dari persamaan di atas maka dapat disimpulkan sebagai berikut:

$52,381=$ Jika motivasi $\left(\mathrm{X}_{1}\right)$ dan disiplin $\left(\mathrm{X}_{2}\right)=0$ atau

konstan, maka produktivitas kerja karyawan akan bernilai 52,381. 0,048= Jika motivasi $\left(\mathrm{X}_{1}\right)$ mengalami peningkatan sebesar

satu satuan, dan motivasi $\left(\mathrm{X}_{2}\right)$ tetap atau konstan, maka produktivitas kerja (Y) hanya akan mengalami peningkatan score sebesar 0,048 .

$$
1,000=\text { Jika disiplin }\left(\mathrm{X}_{2}\right)
$$

mengalami peningkatan sebesarsatu

Tabel 10 Hasil Pengolahan Data Koefisien Determinasi Variabel

Motivasi $\left(\mathbf{X}_{1}\right)$ Dan Disiplin $\left(\mathbf{X}_{2}\right)$

Model Summary

\begin{tabular}{|c|c|c|c|c|}
\hline Model & $\mathrm{R}$ & R Square & Adjusted R Square & Std. Error of the Estimate \\
\hline 1 & $.998^{\mathrm{a}}$ & .996 & .996 & .270 \\
\hline
\end{tabular}

a. Predictors: (Constant), Motivasi (X1), Disiplin (X2)

Um Sumber : Data Primer tahun 2017, diolah dengan SPSS Versi 22.

Dari tabel diatas, diperoleh nilai koefisiendeterminasi sebesar 0,996, maka dapat disimpulkan bahwa variabel Motivasi $\left(\mathrm{X}_{1}\right)$ dan Disiplin $\left(\mathrm{X}_{2}\right)$ berpengaruh terhadap variabel Produktivitas Kerja karyawan (Y) sebesar 99,\% sedangkan sisanya $0,4 \%$ dipengaruhi oleh faktor-faktor lain yang tidak diteliti dalam penelitian ini.

\section{g. Pengujian Hipotesis \\ 1) Uji Parsial (t hitung)}

satuan, dan motivasi $\left(\mathrm{X}_{1}\right)$ tetap atau konstan, maka produktivitas kerja (Y) akan mengalami peningkatan scor sebesar 1,000 .

\section{f. Analisis Koefiisien Determinasi}

Koesfisien Determinasi dipergunakan untuk mengetahui seberapa besar tingkat hubungan atau pengaruh antara variabel Motivasi dan Disiplin terhadap variabel Produktivitas Kerja karyawan.

Adapun cara mengetahui tingkat hubungan tersebut dipergunakan rumus sebagai berikut : $\mathrm{KD}=\mathrm{R}^{2}$ x $100 \%$ yang diolah dengan program SPSS versi 22.

Hasil uji terlihat pada tabel bawah in 
2) Jika $t_{\text {hitung }}>t_{\text {tabel }}$ : berarti $\mathrm{H}_{0}$ ditolak dan $\mathrm{H}_{1}$ diterima $(\alpha=5 \%)$

Adapun untuk untuk menentukan besarnya $\mathrm{t}$ tabel dicari dengan menggunakan rumus berikut ini :

$t_{\text {tabel }}=$ t $\alpha$. df $\quad($ Taraf Alpha $\mathrm{x}$ Degree of Freedom)

$\alpha=$ tarif nyata $5 \%$ df $\quad=(\mathrm{n}-2)$, maka diperoleh

$(60-2)=58$

$$
t_{\text {tabel }}=2,0017
$$

(a) Pengaruh Motivasi $\left(\mathbf{X}_{1}\right)$, Disiplin $\left(\mathrm{X}_{2}\right)$ Terhadap

\section{Produktivitas Kerja (Y)}

Adapun hasil pengolahan data menggunakan program SPSS Versi 22, dengan hasil sebagai berikut :

Tabel 11 Hasil Uji t Variabel Motivasi $\left(\mathbf{X}_{1}\right)$

Coefficients $^{\mathrm{a}}$

\begin{tabular}{|c|c|c|c|c|c|}
\hline \multirow[b]{2}{*}{ Model } & \multicolumn{2}{|c|}{$\begin{array}{r}\text { Unstandardized } \\
\text { Coefficients }\end{array}$} & \multirow{2}{*}{ 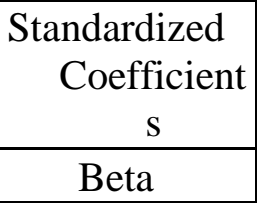 } & \multirow[b]{2}{*}{$\mathrm{T}$} & \multirow[b]{2}{*}{ Sig. } \\
\hline & B & Std. Error & & & \\
\hline $1 \quad$ (Constant) & 52.381 & .352 & & 148.715 & .000 \\
\hline Motivasi (X1) & .048 & .008 & .049 & 6.188 & .000 \\
\hline Disiplin (X2) & 1.000 & .008 & .997 & 127.117 & .000 \\
\hline
\end{tabular}

a. Dependent Variabel: Produktivitas Kerja (Y)

Sumber : Data Primer tahun 20167 diolah dengan SPSS Versi 22.

Dari hasil tabel tersebut diperoleh sebagai berikut:

1) Uji t Pengaruh Motivasi terhadap Produktivitas Kerja (Y)

a. Dari hasil pengujian statistic diperoleh hasil $\mathrm{t}$ hitung $<\mathrm{t}$ tabel yaitu $6,188>2,0017$ dapat diartikan adanya pengaruh positif Motivasi $\left(\mathrm{X}_{1}\right) \quad$ terhadap Produktivitas Kerja karyawan.

b. Dan diperoleh tingkat signifikan sebesar ,000>0,005 sehingga dapat diartikan terdapat pengaruh signifikan Disiplin $\left(\mathrm{X}_{2}\right)$ terhadap Produktivitas Kerja.

c. Penarikan kesimpulan

Karena t hitung nilainya positif, maka dapat disimpulkan bahwa dengan taraf signifikansi 0,05, secara parsial Motivasi $\left(\mathrm{X}_{1}\right)$ memiliki pengaruh positif dan signifikan terhadap Produktivitas Kerja (Y) pada PT. Nadi Suwarna Bumi Jadi, semakin meningkatnya Motivasi $\left(\mathrm{X}_{1}\right)$ maka Produktivitas Kerja (Y) karyawan akan mengalami kenaikan pula.

2) Uji t Pengaruh Disiplin terhadap Produktivitas Kerja (Y) a. Dari hasil pengujian statistik diperoleh $\mathrm{t}$ hitung $>\mathrm{t}$ tabel yaitu $127,117>2,0017$ dapat diartikan adanya pengaruh positif Disiplin terhadap Produktivitas Kerja karyawan

b. Dan diperoleh tingkat signifikan sebesar $0,000<0,005$ sehingga dapat diartikan terdapat pengaruh signifikan Disiplin terhadap Produktivitas Kerja karyawan

c. Penarikan kesimpulan

Karena $t$ hitung nilainya positif, maka dapat disimpulkan bahwa dengan taraf signifikansi 0,005 secara parsial disiplin $\left(\mathrm{X}_{2}\right)$ memiliki pengaruh positif dan signifikan terhadap Produktivitas Kerja (Y) pada PT. Nadi Suwarna Bumi Jadi, semakin meningkatnya Disiplin (X2) maka Produktivitas Kerja (Y) akan mengalami kenaikan pula.

\section{2) Uji F (Simultan)}

Untuk pengujian pengaruh variabel Motivasi $\left(\mathrm{X}_{1}\right)$ dan Disiplin $\left(\mathrm{X}_{2}\right)$ secara simultan terhadap Produktivitas Kerja (Y) dapat dilakukan dengan uji statistik F (uji simultan). Sebagai pembanding untuk melihat pengaruh signifikan, maka 
digunakan kriteria signifikan 5\% $(0,05)$ dan membandingkan antara $F$ hitung dengan $F_{\text {tabel }}$ dengan ketentuan sebagai berikut :

a) Jika $F_{\text {hitung }}<F_{\text {tabel }}$ : berarti $\mathrm{H}_{0}$ diterima dan $\mathrm{H}_{1}$ ditolak $(\alpha=5 \%)$

b) Jika $F_{\text {hitung }}>F_{\text {tabe }}$ : berarti $\mathrm{H}_{0}$ ditolak dan $\mathrm{H}_{1}$ diterima $(\alpha=5 \%)$
Adapun untuk untuk menentukan besarnya $F_{\text {tabel }}$ dicari dengan ketentuan : $\alpha$ tarif nyata $5 \%$, df $=(\mathrm{n}-\mathrm{k}), \quad$ maka diperoleh $(60-2)=58$

$F_{\text {tabel }}=3,160$, Adapun hasil pengolahan data pengujian $\mathrm{F}$ menggunakan program SPSS Versi 22, dengan hasil sebagai berikut :

Tabel 12

Hasil Pengolahan Data Pengujian F Simultan

ANOVA $^{\mathrm{a}}$

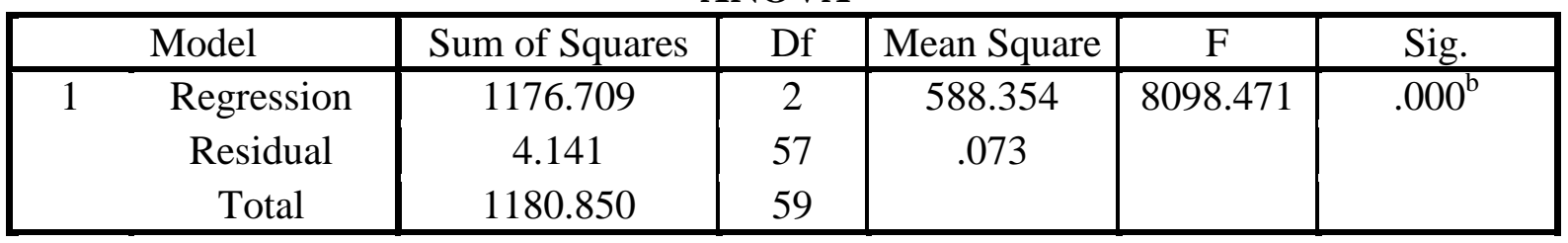

a. Dependent Variabel: Produktivitas Kerja

b. Predictors: (Constant), Disiplin, Motivasi

Sumber : Data Primer tahun 2017, diolah dengan SPSS Versi 22.

Dari Tabel diatas, diperoleh nilai $\mathrm{F}$ hitung $=8098,471>3,160$ atau $\left(F_{\text {hitung }}>\right.$ $\left.F_{\text {tabel }}\right)$ sehingga $\mathrm{H}_{0}$ ditolak dan $\mathrm{H}_{1}$ diterima. Artinya terdapat pengaruh positif dan signifikan secara simultan antara motivasi dan Disiplin $\left(\mathrm{X}_{2}\right)$ secara simultan terhadap Produktivitas kerja (Y) karyawan pada PT. Nadi Suwarna Bumi

\section{G. Pembahasan}

Penelitian ini bertujuan untuk mengetahui pengaruh motivasi dan disiplin terhadap produktivitas kerja karyawan.

\section{Pengaruh Motivasi terhadap Produktivitas Kerja karyawan Pada PT. Nadi Suwarna Bumi}

Hasil penelitian ini menunjukan bahwa variabel motivasi berpengaruh positif terhadap produktivitas kerja karyawan pada PT. Nadi Suwarna Bumi. Hal ini dibuktikan dengan hasil statistik uji $\mathrm{t}>$ tabel $(6,188>2,0017)$. Kontribusi pengaruh motivasi terhadap Produktivitas kerja karyawan sebesar 0,048; maka penelitian ini berhasil membuktikan hipotesis ke dua.

\section{Pengaruh Disiplin terhadap Produktivitas Kerja karyawan Pada PT. Nadi Suwarna Bumi}

Hasil penelitian menunjukan bahwa variabel Disiplin berpengaruh positif terhadap produktivitas kerja karyawan pada PT. Nadi Suwarna Bumi. Hal ini dibuktikan dengan hasil statistik uji $\mathrm{t}>$ tabel $(127,117>2,0017)$. Kontribusi pengaruh disiplin karyawan pada PT. Nadi Suwarna Bumi sebesar 1,000; maka dapat disimpulkan bahwa penelitian berhasil membuktikan hipotesis pertama.

Disiplin dapat dipengaruhi oleh semangat kerja karyawan, tingkat kompensasi yang diberikan, serta kepuasan kerja karyawan. Dimana karyawan dengan semangat kerja yang tinggi cenderung akan bekerja lebih baik, tepat waktu dan juga tidak pernah membolos. Dengan dilandasi aspek tersebut maka kedisiplinan akan berpengaruh besar terhadap produktivitas kerja karyawan. Ketika tingkat disiplin di suatu perusahaan itu tinggi, maka diharapkan karyawan akan bekerja lebih baik dan produktivitas kerja akan meningkat.

Penelitian ini relevan dengan penelitian sebelumnya yang dilakukan oleh Annisa Pratiwi (2014) dengan judul "Pengaruh Motivasi dan Disiplin terhadap Produktivitas Kerja Karyawan PT. Telekomunikasi Indonesia, Tbk Wilayah 


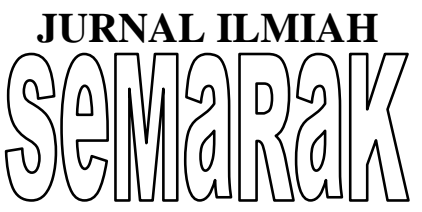

Telkom Pekalongan”. Hasil penelitian ini menunjukan bahwa variabel disiplin mempengaruhi produktivitas kerja karyawan.

\section{Pengaruh Motivasi dan Disiplin terhadap Produktivitas Kerja karyawan Pada PT. Nadi Suwarna Bumi}

Hasil penelitian ini menunjukan bahwa variabel Motivasi dan Disiplin berpengaruh positif dan simultan terhadap Produktivitas kerja karyawan pada PT. Nadi Suwarna Bumi. Hal ini dibuktikan dengan hasil nilai $\mathrm{F}$ hitung $=8098,471>$ 3,160 atau $\left(F_{\text {hitung }}>F_{\text {tabel }}\right)$ sehingga $\mathrm{H}_{0}$ ditolak dan $\mathrm{H}_{1}$ diterima. Artinya terdapat pengaruh positif dan signifikan secara simultan antara motivasi dan Disiplin $\left(\mathrm{X}_{2}\right)$ secara simultan terhadap Produktivitas kerja (Y) karyawan pada PT. Nadi Suwarna Bumi

\section{H. Kesimpulan}

Berdasarkan hasil penelitian serta analisis yang telah dilakukan dan pembahasan - pembahasan yang telah diuraikan dalam bab sebelumnya, maka dapat disimpulkan sebagai berikut:

1. Secara Simultan, Motivasi $\left(X_{1}\right)$ dan Disiplin $\left(\mathrm{X}_{2}\right)$ memberikan pengaruh kepada Produktivitas kerja karyawan (Y) pada PT. Nadi Suwarna Bumi, hal ini dibuktikan dengan nilai signifikansi pada uji $\mathrm{F}$ yang kurang dari 0,005 .

2. Secara Parsial, Motivasi $\left(X_{1}\right)$ dan Disiplin $\left(\mathrm{X}_{2}\right)$ memberikan pengaruh kepada Produktivitas kerja karyawan (Y) pada PT. Nadi Suwarna Bumi, hal ini dibuktikan dengan nilai signifikansi pada uji t yang kurang dari 0,005 .

3. Terdapat hubungan Kausal antara Motivasi $\left(\mathrm{X}_{1}\right)$ dan Disiplin $\left(\mathrm{X}_{2}\right)$ dengan Produktivitas kerja karyawan (Y) pada PT. Nadi Suwarna Bumi. Hal ini dibuktikan dengan rumusan hasil analisis regresi linear berganda yang dihasilkan adalah $\mathrm{Y}$ $=52,381+0,048 \mathrm{X}_{1}+1,000 \mathrm{X}_{2}$. Pada formula atau rumus tersebut menjelaskan bahwa setiap kali variabel Motivasi $\left(\mathrm{X}_{1}\right)$ dan Disiplin $\left(\mathrm{X}_{2}\right)$ mengalami kenaikan, maka variabel Produktivitas Kerja (Y) akan mengalami kenaikan, begitu pula sebaliknya, ketika variabel Motivasi $\left(\mathrm{X}_{1}\right)$ dan Disiplin $\left(\mathrm{X}_{2}\right)$ mengalami penurunan, maka variabel Produktivitas Kerja (Y) juga mengalami penurunan.

4. Variabel Motivasi $\left(\mathrm{X}_{1}\right)$ dan Variabel Disiplin $\left(\mathrm{X}_{2}\right)$ secara bersama sama mempunyai pengaruh positif dan signifikan terhadap produktivitas kerja karyawan (Y) dengan nilai Fhitung > Ftabel sebesar 8098,471 > 3,160 dan nilai koefisien determinasi sebesar 0,996 atau sebesar 99,6\%. Artinya kedua variabel independen dapat menjelaskan dependen sebesar 99,6\% dan sisanya sebesar 0,4\% dijelaskan oleh variabel penelitian lain.

\section{Daftar Pustaka}

Hasibuan, Melayu. 2013. Manajemen

Sumber Daya Manusia Edisi Revisi.

Jakarta: Bumi Aksara

Mangkunegara, A. Prabu. 2013.

Manajemen Sumber Daya Manusia.

Bandung: PT. Remaja Rosdakarya

Priyatno, Duwi. 2014. Paham Analisis

Statistik Data Dengan SPSS.

Yogyakarta : MediaKom.

Rivai, Veitzhal. 2011. Manajemen Sumber

Daya Manusia Untuk Perusahaan

Edisi ke-2. Jakarta: PT. Raja

Grafindo

Sugiyono. 2014. Metode Penelitian

Kuantitatif dan Kualitatif

$R \& D$.Bandung :Alfabeta

Sutrisno, Edy. 2016. Manajemen Sumber

Daya Manusia. Jakarta: Kencana

Wibowo. 2014. Manajemen Kinerja. Jakarta: Rajawali Press. 